\title{
Coral colonization and fish assemblage on an artificial reef off Hurghada, Red Sea, Egypt
}

\author{
Mohammed M. A. Kotb \\ Marine Science Department, Faculty of Science, Suez Canal University, 41511, \\ Ismailia, Egypt. \\ E-mail: Kotb13@gmail.com
}

\section{ABSTRACT}

Artificial reefs were deployed as underwater scenery for recreational purpose and monitored for fishes and corals colonization during 2001, 2005 and 2010. The diversity of the newly coral colonies showed a clear trend of increase over years. The number of newly settled coral colonies increased significantly from 1897 in year 2005 to 2040 colonies in year 2010. The fish abundance in the area of the artificial reef increased from 120 in year 2001 to 17403 individuals in year 2010. The fish diversity increased from 14 to 112 species between years 2001 and 2010. The successful colonization of corals and fishes on the artificial reefs supports the approach of installing artificial reefs to be an effective rehabilitation and conservation method to reduce the potential impact of recreational activities on the Egyptian natural reefs.

Keywords: Coral reef, colonization, conservational approach, long monitoring, Rea Sea, Egypt.

\section{INTRODUCTION}

Artificially built reefs are considered one of the reef management strategies to help remedy the negative effects of human activities on natural coral reef ecosystems. Worldwide, artificial reef implementation is widely used and apparently accepted by the public and resource managers, yet its scientific foundation is far from complete. Even so, there are major potential benefits of artificial reefs, which make them a widely used tool in marine natural resources conservation and management (Seaman, 2000;Precht, 2006; Edwards and Gomez, 2007; Edwards, 2010). The worldwide deterioration of reefs, particularly in the last decades, has directed more attention to the prospects of mitigation activities. The variety of mitigation activities ranges from species reintroduction and coral transplantation to enhancement of recruitment potential and artificial reefs (Grove, 1982; Edwards and Clark, 1998; Clark and Edwards, 1999; Yap, 2000, 2003; Epstein et al., 2003).

There are several potential environmental benefits from artificial reefs. Firstly, they are expected to contribute to the conservation of natural reefs by diverting human activities from them (van Treeck and Schuhmacher, 1999). Secondly, artificial reefs can offer refuge for rare and endangered species of invertebrates and fish. Third, artificial reefs may provide nursery grounds for young stages of reef species (Collins and Jensen, 1996). If the artificial reef is situated away from any natural reefs, low coral larval supply is expected to limit the effectiveness of the artificial reef (Edwards and Gomez, 2007; Edwards, 2010). However, the evidencessupportthat coral transplantation actually increases settlement and recruitment are scarce (Ferseet al., 2013). On the other hand, the environmental conditions at the artificial reef site have great effects on the faunal and floral communities which will inhabit the reefs, and will determine how much the artificial reef succeed in fulfilling its original target of construction (Seaman, 2000; Edwards and Gomez, 2007). 
The Egyptian Red Sea constitutes a major tourism destination, especially for diving, and the coral reefs are suffering from different human impacts (Kotb et al., 2001; Kotb et al., 2008). Several large glass-bottom boats are operating for tourists in the Hurghada area, and one project operates submarines. As a management and conservation tool, all the glass-bottom boats have fixed authorized routes for operating on certain natural reefs off Hurghada coast. For the submarine, because of its type of operation as well as due to the potential hazards for the natural reefs, the Egyptian authority ceased the operation of the submarine recreational project (Sindbad), which started to operate in 1999 in a natural reef area. Installing artificial reefs in 2000 was seen as a solution to create underwater scenery for operating the submarine. The present work investigates the recruitment rate of coral colonies as well as the fish assemblage colonizing the artificial reefs over 10 years period after installation. It is worth to mention that these artificial reefsare the first to be deployed andmonitored for long-period in the Egyptian Red Sea region.

\section{MATERIALS AND METHODS}

The submarine operation site is locating off Hurghada (Fig. 1). The site is characterized by soft bottom substrate with scattered rocks covering $15-20 \%$. Rocks with coral cover ranged between 5 and 10\%. The water depth ranged between 12 and $20 \mathrm{~m}$. It is observed that most of the newly recruiting colonies are dying shortly after settlement due to the heavy sediment re-suspension over the sea floor, either by suffocation or by being buried under the sediments. The sedimentation is due to the soft substrate and the prevailing north-south currents occurring almost year-round. In addition, the site is located south of the main shoreline of Hurghada city. This shoreline suffered for a long time (during 1980s and early 1990s) from intensive landfilling operations, mostly by using non-proper materials with a high content of silt and clay. As a result, the loading of fine sediments was particularly high in the artificial reef area and increased the sedimentation and turbidity rates.

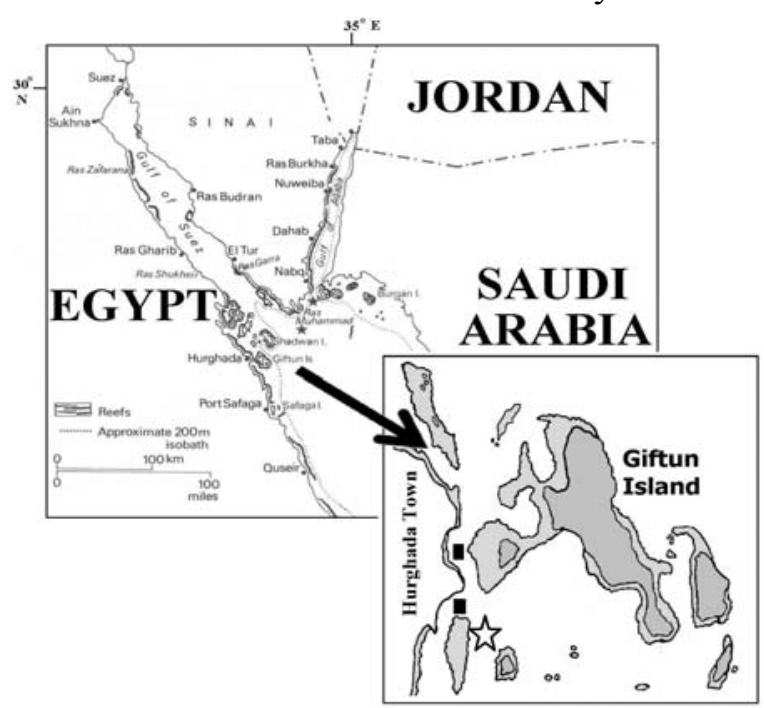

Fig.1: Location of the study site (indicated by a star) off Hurghada coast at the northern Red Sea. The black dots are indicating the locations of the nearby anchoring areas to the north of the study site.

A number of artificial structures made of fiber-glass were deployed (early 1990) at the site to form the boundaries of the designated location. Afterwards, between 
2001 and 2002, several other structures made of car tires covered with fossilized coral boulders and rocks were built and installed. The fossilized coral boulders and rocks were brought from inshore excavation activities of coastal development operations (e.g. resorts). The artificial reefs were built as units, each about $10 \mathrm{~m}$ width, $5-7 \mathrm{~m}$ length, and $3-8 \mathrm{~m}$ height. The uppermost surfaces of the artificial reefs are submerged at depths of $5-8 \mathrm{~m}$ depths. All the units of the artificial reef were placed at a straight line of about $150 \mathrm{~m}$ length, following the natural slope grid of the bottom (Fig. 2) to suite the requirements for the submarine operation.

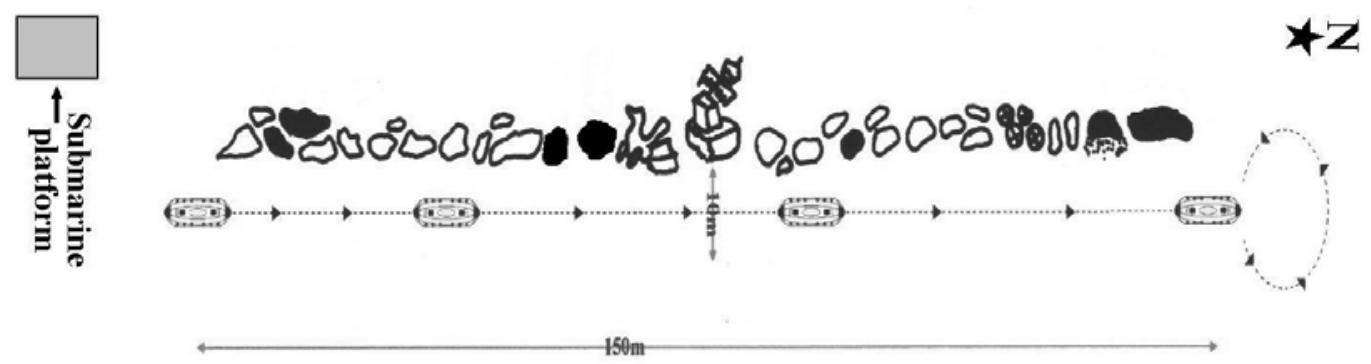

Fig. 2: The underwater submarine project scenery showing the layout of the artificial substrate and the submarine route alongside these reefs. The total length of the artificial reefs reached about $150 \mathrm{~m}$.

\section{Coral colonization and fish assemblage measurements:}

To enhance and accelerate the colonization of the artificial reef, 412 hard and soft coral colonies were transplanted onto the installed artificial reefs in 2001. The transplantation technique and survivorship data of the transplanted corals were given by Kotb (2003). In the present study, new recruits as well as the mature coral colonies of hard and soft corals were identified on species/genus level and counted on the total surface area of the artificial reef (estimated at $1500 \mathrm{~m}^{2}$ area) during the years 2001, 2005 and 2010. Surveys and data collection were conducted using scuba diving, and in each survey, three types of data sets were collected including: counts of new coral recruits of $1-5 \mathrm{~cm}$ size diameters (i.e. sizes of genus identification); counts of mature coral colonies (i.e. more than $5 \mathrm{~cm}$ diameter) and estimation of fish abundance. The new coral recruits were counted and identified to the species/genus level as much as possible according to Babcock et al. (2003). Mature coral colonies were counted and identified to the species/genus level. The fish abundances were estimated alongside the artificial reef using the belt transect fish census technique (English et al., 1997). The fishes were identified to species level and counted alongside the artificial reef structures $\left(10000 \mathrm{~m}^{3}\right.$ area).

Different physicochemical parameters were estimated once, just before the installation of the artificial reef, in comparison with the selected control site of El-Fanadir reef, north of Hurghada. Sedimentation rate was estimated using sediment traps according to English et al. (1997). Four sediment traps were installed at depths of 5-10m alongside the artificial reef area. Each sediment trap was covered with ironmesh nets (mesh size of $0.5 \mathrm{~cm}$ and secured above the bottom. The nets were used to prevent fishes, crustaceans or mollusks from entering and re-suspending the sediment collected in the bottles. After one month, the sediment traps were collected and sedimentation rates as $\mathrm{mg} / \mathrm{cm}^{2} /$ day were determined by dividing the dry weight (in $\mathrm{mg}$ ) by the area of the sediment trap aperture width (in $\mathrm{cm}^{2}$ ) and the duration (in days). Other physicochemical parameters, including water temperature, total suspended solids (TSS), salinity, $\mathrm{pH}$, dissolved oxygen and nutrients (nitrate and phosphate) and chlorophyll- $a$ were measured. 


\section{RESULTS}

The values of physicochemical parameters measured at the control and the artificial reef sites showed similar values except for TSS and sedimentation rate values (Table 1). Much higher values of TSS and sedimentation rate were recorded at the artificial reef site compared to the control site, with 38 and $13 \mathrm{mg} / 1$, and 4.1 and $2.7 \mathrm{mg} / \mathrm{cm}^{2} /$ day, respectively.

Table 1: The physicochemical parameters in the study site and the control site (northern of Hurghada, Fanadir reef), measured during the installation of the artificial reef.

\begin{tabular}{|l|c|c|}
\hline \multicolumn{1}{|c|}{ Parameters } & $\begin{array}{c}\text { Annual average } \\
\text { (control site) }\end{array}$ & $\begin{array}{c}\text { Annual average } \\
\text { (study area) }\end{array}$ \\
\hline Water temperature & 23.7 & 23.7 \\
\hline TSS $(\mathrm{mg} / \mathrm{L})$ & 13 & 38 \\
\hline Salinity $(\mathrm{ppt})$ & 40.4 & 40.4 \\
\hline $\mathrm{pH}$ & 8.1 & 8.1 \\
\hline Sedimentation rate $\left(\mathrm{mg} / \mathrm{cm}^{2} /\right.$ day $)$ & 2.7 & 4.1 \\
\hline Dissolved oxygen $(\mathrm{mg} / \mathrm{L})$ & 7.2 & 7.2 \\
\hline Nitrate $(\mu \mathrm{g}$ atm $/ \mathrm{L})$ & 0.7 & 0.7 \\
\hline Phosphate $(\mu \mathrm{g}$ atm $/ \mathrm{L})$ & 0.28 & 0.28 \\
\hline Chlorophyll $a\left(\mathrm{mg} / \mathrm{m}^{3}\right)$ & 0.61 & 0.61 \\
\hline
\end{tabular}

\section{Coral colonization}

Coral diversity on the surface area of the artificial reef, in terms of number of coral species, showed a clear trend of increase with years (Table 2). In total coral, diversity increased from 18 species (representing 12 genera) in 2001 to 44 species (representing 28 genera) in 2005 and 45 species (representing 29 genera) in 2010. Highest species diversity in all years was recorded for the order Alcyonacea, with 3, 7, and 8 species, the genus Faviidae, with 6, 7, and 7 species and the genus Acroporidae, with 4, 7, and 7 species, respectively (Fig. 3).

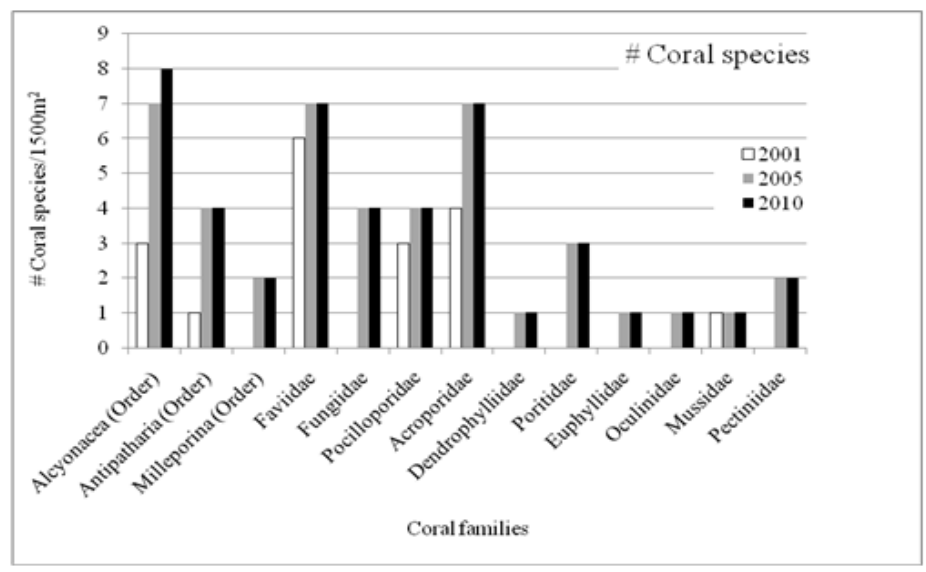

Fig. 3: The coral diversity, as a number of species, recorded on the surface area of the artificial reef, during 2001, 2005 and 2010.

The number of newly recruited coral colonies on the investigated artificial reef increased significantly from 1897 colonies $/ 1500 \mathrm{~m}^{2}$ in 2005 to 2040 colonies $/ 1500 \mathrm{~m}^{2}$ in 2010 (Table 2). During the 2005 survey, highest estimated recruitment rates were recorded for the hard coral species of the families, Pocilloporidae (594 
colonies $\left./ 1500 \mathrm{~m}^{2}\right), \quad$ Poritidae $\quad\left(465\right.$ colonies $\left./ 1500 \mathrm{~m}^{2}\right)$, and Faviidae $(302$ colonies $\left./ 1500 \mathrm{~m}^{2}\right)$.

Table 2: Summary of the recorded coral data at the study site (the estimated available area for coral settlement and growth is $1500 \mathrm{~m}^{2}$ ).

\begin{tabular}{|c|c|c|c|c|c|c|c|c|c|c|c|c|}
\hline \multirow[b]{2}{*}{ Family } & \multicolumn{4}{|c|}{2001} & \multicolumn{4}{|c|}{2005} & \multicolumn{4}{|c|}{2010} \\
\hline & 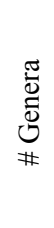 & 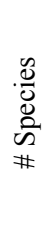 & 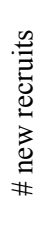 & 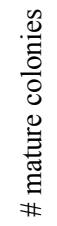 & 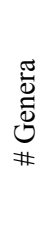 & $\begin{array}{l}\frac{\tilde{U}}{U} \\
\stackrel{\tilde{U}}{0} \\
\text { की } \\
\#\end{array}$ & 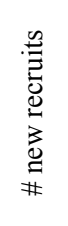 & 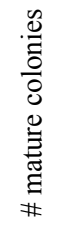 & 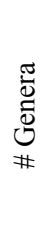 & $\begin{array}{l}\frac{\tilde{U}}{\tilde{U}} \\
\stackrel{\tilde{U}}{0} \\
\text { की } \\
\#\end{array}$ &  & 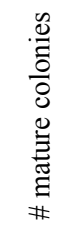 \\
\hline Alcyonacea (Order) & 3 & 3 & 0 & 82 & 7 & 7 & 299 & 164 & 8 & 8 & 691 & 256 \\
\hline Antipatharia (Order) & 1 & 1 & 0 & 15 & 1 & 4 & 63 & 120 & 1 & 4 & 120 & 235 \\
\hline Milleporina (Order) & 0 & 0 & 0 & 0 & 1 & 2 & 59 & 84 & 1 & 2 & 30 & 132 \\
\hline Faviidae & 3 & 6 & 0 & 65 & 4 & 7 & 302 & 102 & 4 & 7 & 295 & 179 \\
\hline Fungiidae & 0 & 0 & 0 & 0 & 2 & 4 & 0 & 50 & 2 & 4 & 45 & 69 \\
\hline Pocilloporidae & 3 & 3 & 0 & 202 & 3 & 4 & 594 & 313 & 3 & 4 & 365 & 432 \\
\hline Acroporidae & 1 & 4 & 0 & 33 & 2 & 7 & 110 & 74 & 2 & 7 & 155 & 119 \\
\hline Dendrophylliidae & 0 & 0 & 0 & 0 & 1 & 1 & 5 & 20 & 1 & 1 & 5 & 32 \\
\hline Poritidae & 0 & 0 & 0 & 0 & 2 & 3 & 465 & 15 & 2 & 3 & 315 & 38 \\
\hline Euphyllidae & 0 & 0 & 0 & 0 & 1 & 1 & 0 & 10 & 1 & 1 & 5 & 19 \\
\hline Oculinidae & 0 & 0 & 0 & 0 & 1 & 1 & 0 & 15 & 1 & 1 & 5 & 20 \\
\hline Mussidae & 1 & 1 & 0 & 15 & 1 & 1 & 0 & 16 & 1 & 1 & 3 & 22 \\
\hline Pectiniidae & 0 & 0 & 0 & 0 & 2 & 2 & 0 & 10 & 2 & 2 & 6 & 17 \\
\hline Total: & 12 & 18 & 0 & 412 & 28 & 44 & 1897 & 993 & 29 & 45 & 2040 & 1570 \\
\hline
\end{tabular}

In contrast, during the 2010 survey, the highest recruitment rates were recorded for the soft coral species of the order Alcyonacea $\left(691\right.$ colonies $\left./ 1500 \mathrm{~m}^{2}\right)$, followed by Pocilloporidae $\left(365\right.$ colonies $\left./ 1500 \mathrm{~m}^{2}\right)$, Poritidae $\left(315\right.$ colonies $\left./ 1500 \mathrm{~m}^{2}\right)$, and Faviidae (295 colonies $\left./ 1500 \mathrm{~m}^{2}\right)$, (Fig. 4). On the genus level, the highest occurrence of new recruited soft corals was estimated for 4 genera of Alcyonacea (Sarcophyton sp., Dendronephthya sp., Xenia sp. and Heteroxenia sp.), and for the two hard coral genera, Faviidae (Favia sp. and Favites sp.), 3 species of Pocilloporidae (Pocillopora damicornis, P. verrucosa and Stylophora pistillata), and 2 species of Poritidae (Porites sp.).

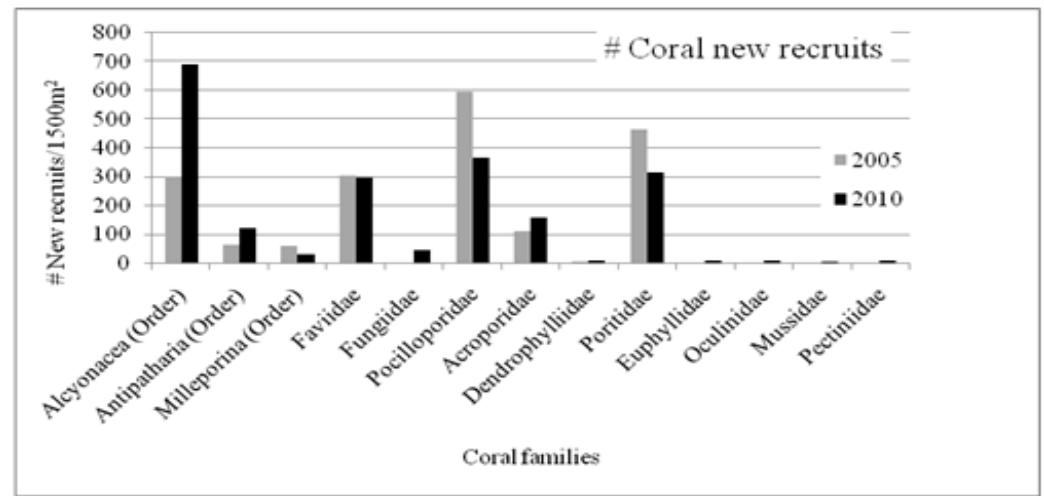

Fig. 4: The abundance of newly recruited colonies recorded for the different coral families during 2005 and 2010.

The number of newly recruited and transplanted coral colonies increased significantly from 412 (the transplanted colonies) at the start of the study in 2001, to 993 and 1570 colonies at 2005 and 2010 respectively (Table 2). The highest 
occurrences were recorded for the hard coral Pocilloporidae, 313 and 432, followed by the soft coral Alcyonacea, with 164 and 256 colonies in 2005 and 2010 respectively (Fig. 5). Regarding species, the highest recorded numbers of mature colonies were for 3 species of Pocilloporidae (Pocillopora damicornis,P. verrucosa and Stylophora pistillata), 2 genera of Alcyonacea (Sarcophyton sp. and Sinularia sp.), 1 species of Antipatharia (Antipatharia sp.) and 3 genera of Faviidae (Favia sp., Favites sp., and Echinopora sp.).

\section{Fish community}

Fish abundance and diversity on the investigated area of the artificial reef increased significantly over the years $(\mathrm{P}<0.05)$. The abundance increased from a total count of 120 fish in 2001 to 16718 and $17403 \mathrm{fish} / 10000 \mathrm{~m}^{3}$ in 2005 and 2010 , respectively (Table 3 ). Regarding species, the total number of fish species increased from only 14 species in 2001 (represented 9 families) to 112 species in 2005 and 2010, representing 33 families (Table 3).

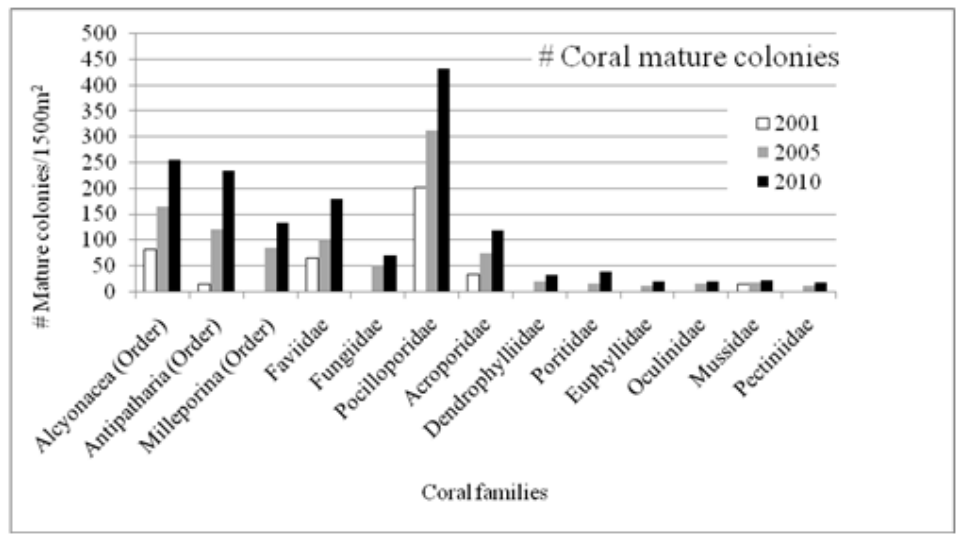

Fig.5: The number of newly recruited mature colonies recorded for different coral families during 2001 (only the transplanted colonies), 2005 and 2010 (the survived transplanted colonies + the newly recruited colonies).

Based on trophic categories, the carnivorous fish species comprised the highest numbers, increasing from only 10 species representing 5 families in 2001 up to 62 species in 2005 and 2010 (18 families). Herbivore and omnivore fish species increased from only one species in 2001 to 17 (5 families) and 22 species (6 families) in 2005 and 2010, respectively. In contrast, the lowest diversity was recorded for the planktivore fish species, which increased from 2 species in 2001 to 11 species in both 2005 and 2010 (Table 3 and Fig. 6).

The fish abundance of different trophic categories is given in Table (3). The omnivore fishes dominated the fish assemblage on the artificial reef territory with 8745 and 9733 fish $/ 10000 \mathrm{~m}^{3}$ in 2005 and 2010 , respectively. On the other hand, herbivore fishes displayed the lowest abundance, with 763 and 755 fish $/ 10000 \mathrm{~m}^{3}$, respectively. During 2001, the carnivore fishes had the highest abundance, with 85 fishout of a total of $120 \mathrm{fish} / 10000 \mathrm{~m}^{3}$ (Fig. 7). 
Table 3: Fish diversity, as a number of species and abundance, individuals $/ 10000 \mathrm{~m}^{3}$, recorded on the artificial reef area during 2001, 2005 and 2010.

\begin{tabular}{|c|c|c|c|c|c|c|c|}
\hline \multirow{2}{*}{ Feeding type } & \multirow{2}{*}{ Family } & \multicolumn{2}{|c|}{2001} & \multicolumn{2}{|c|}{2005} & \multicolumn{2}{|c|}{2010} \\
\hline & & \# Sp. & \# Indiv. & \# Sp. & \# Indiv. & \# Sp. & \# Indiv. \\
\hline \multirow{18}{*}{ Carnivore } & Dasyatididae & 0 & 0 & 1 & 8 & 1 & 10 \\
\hline & Synodontidae & 0 & 0 & 2 & 85 & 2 & 60 \\
\hline & Belonidae & 0 & 0 & 1 & 15 & 1 & 20 \\
\hline & Fistulariidae & 0 & 0 & 1 & 11 & 1 & 25 \\
\hline & Gobiidae & 2 & 17 & 3 & 42 & 3 & 70 \\
\hline & Ephippidae & 0 & 0 & 1 & 7 & 1 & 35 \\
\hline & Ostraciidae & 0 & 0 & 2 & 14 & 2 & 25 \\
\hline & Haemulidae & 0 & 0 & 3 & 40 & 3 & 45 \\
\hline & Scorpaenidae & 0 & 0 & 2 & 7 & 2 & 10 \\
\hline & Chaetodontidae & 4 & 31 & 10 & 86 & 10 & 120 \\
\hline & Labridae & 1 & 3 & 10 & 522 & 10 & 510 \\
\hline & Holocentridae & 2 & 17 & 5 & 67 & 5 & 70 \\
\hline & Serranidae & 1 & 10 & 4 & 266 & 4 & 175 \\
\hline & Pseudochromidae & 0 & 0 & 3 & 443 & 3 & 625 \\
\hline & Carangidae & 0 & 0 & 3 & 153 & 3 & 205 \\
\hline & Lutjanidae & 0 & 0 & 5 & 96 & 5 & 105 \\
\hline & Lethrinidae & 0 & 7 & 3 & 775 & 3 & 730 \\
\hline & Sparidae & 0 & 0 & 3 & 117 & 3 & 115 \\
\hline \multicolumn{2}{|c|}{ Sub-total: 18} & 10 & 85 & 62 & 2754 & 62 & 2955 \\
\hline \multirow{4}{*}{ Planktivore } & Priacanthidae & 0 & 0 & 1 & 15 & 1 & 20 \\
\hline & Caesionidae & 0 & 0 & 4 & 2635 & 4 & 1780 \\
\hline & Mullidae & 1 & 5 & 3 & 1756 & 3 & 2110 \\
\hline & Pomacanthidae & 1 & 20 & 3 & 50 & 3 & 50 \\
\hline \multicolumn{2}{|c|}{ Sub-total: 4} & 2 & 25 & 11 & 4456 & 11 & 3960 \\
\hline \multirow{5}{*}{ Herbivore } & Syngnathidae & 0 & 0 & 2 & 123 & 2 & 110 \\
\hline & Scaridae & 1 & 3 & 6 & 51 & 6 & 55 \\
\hline & Acanthuridae & 0 & 0 & 6 & 191 & 6 & 190 \\
\hline & Siganidae & 0 & 0 & 2 & 385 & 2 & 390 \\
\hline & Balistidae & 0 & 0 & 1 & 13 & 1 & 10 \\
\hline \multicolumn{2}{|c|}{ Sub-total: 5} & 1 & 3 & 17 & 763 & 17 & 755 \\
\hline \multirow{6}{*}{ Omnivore } & Pomacentridae & 1 & 7 & 12 & 6890 & 12 & 7830 \\
\hline & Tetraodontidae & 0 & 0 & 5 & 41 & 5 & 48 \\
\hline & Echeneididae & 0 & 0 & 1 & 2 & 1 & 5 \\
\hline & Nemipteridae & 0 & 0 & 1 & 1750 & 1 & 1800 \\
\hline & Apogonidae & 0 & 0 & 2 & 37 & 2 & 30 \\
\hline & Mugiloididae & 0 & 0 & 1 & 25 & 1 & 20 \\
\hline \multicolumn{2}{|c|}{ Sub-total: 6} & 1 & 7 & 22 & 8745 & 22 & 9733 \\
\hline \multicolumn{2}{|c|}{ TOTAL: $\quad 33$} & 14 & 120 & 112 & 16718 & 112 & 17403 \\
\hline
\end{tabular}

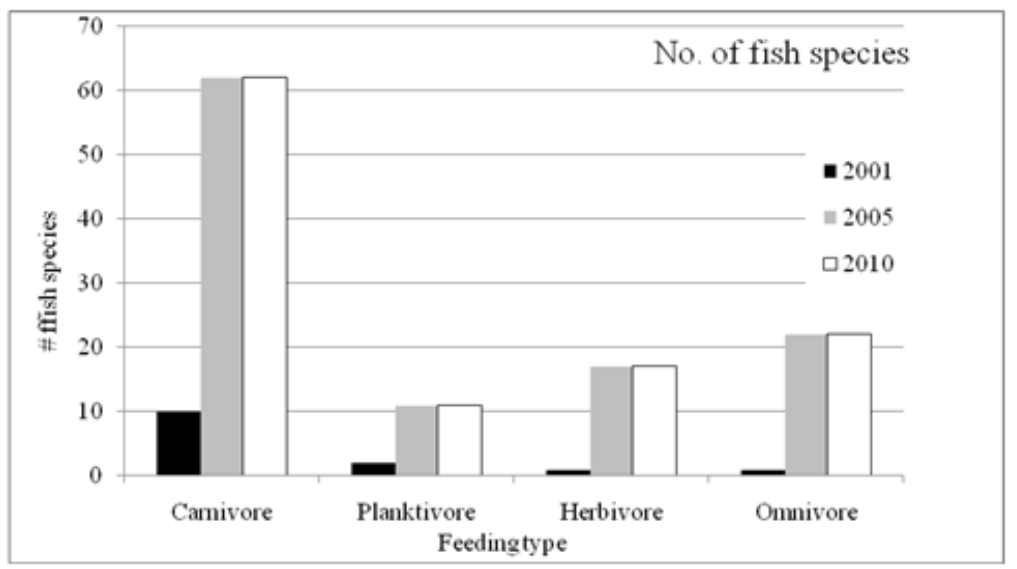

Fig. 6: The recorded fish species at the artificial reef area $\left(10000 \mathrm{~m}^{3}\right)$ in years 2001,2005 and 2010. 


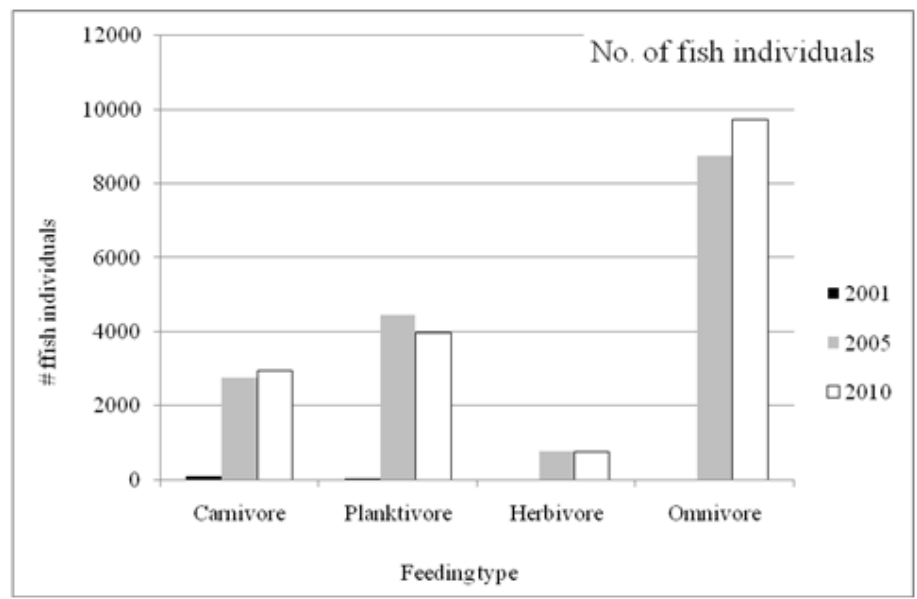

Fig. 7: The recorded fish abundances at the artificial reef area $\left(10000 \mathrm{~m}^{3}\right)$ in years 2001,2005 and 2010.

In term of abundance, the four families of Caesionidae, Mullidae, Pomacenthridae and Nemipteridae were dominated the fish assemblage on the investigated artificial reef territory (Table 3). Out of the recorded 112 coral reef fish species, 6 species only represented more than $60 \%$ of the total fish counts, namely, Caesio suevicus, Mulloides vanicolensis, Neopomacentrus cyanomos, Amblyglyphidon leucogaster, Amblyglyphidon flavilatus and Scolopis ghanam.

\section{DISCUSSIONS AND CONCLUSIONS}

One of the oldest and most common uses of the artificial reefs around the world is fish attraction (Seaman and Sprague, 1991; Seaman, 2000). Most of the deployed artificial reefs attracted fishes within a few days and established a rich and abundant fish community within a few months to years. Zaidnuddinet al. (2000) investigated the effectiveness of artificial reef deployment and fish standing stock in its vicinity at PulauPayar, Malaysia. He concluded the success of the artificial reef in increasing fish abundance and richness at and around the artificial reef. Edwards (2010) summarized the details of some worldwide artificial reef projects. It is obvious that the artificial reef under investigation encouraged enhancing fish aggregations in regard to species richness and abundance as well as coral colonization.

The colonization of the artificial reef by coral colonies was influenced by the recorded high sedimentation rates. In terms of species richness, the family Alcyonacea soft corals and families of Faviid and Acroporid hard corals were the most successful genera inhabiting the artificial reefs. In terms of abundance, however, hard corals of the family Pocilloporidae were the most dominant. On the other hand, the hard corals of Pocillopora spp. had the highest survival rate among other coral species and were estimated as having the highest number of mature colonies in 2010. In contrast, Acroporidae species showed the lowest success in thriving in such turbid conditions. Arthur et al. (2006) investigated the survival of newly recruited corals in atoll reefs at Lakshadweep, Indian Ocean between 2000 and 2003. They found that not all the new recruits survived to continue growing, and only the coral species which can tolerate the ambient existing environmental conditions could survive. Coles (2003) studied the coral community composition at the Arabian Gulf area in relation to the environmental conditions. He reported more successful occurrence of Dendrophylliidae (Alcyonacea) and Faviidae in areas of the turbidity. 
Generally, the recorded coral recruits show that the artificial reefs receive coral planulae in the reproductive season (Edwards and Gomez, 2007; Edwards, 2010), and in the study site high numbers of new recruits, in terms of species or abundance, were recorded throughout the survey time. In addition, most of the recorded recruiting species were not transplanted into the area during 2001 and the settled larvae must thus be originating from nearby reef areas. This may indicate that the selected site for the artificial reef, regardless of the high sedimentation, is a quite adequate location for coral planulae. On the other hand, the recorded increase of mature colonies through time was very low compared to the recorded high number of new recruits. This indicates a failure of most of the new recruits to continue growing to maturation. This trend is common in areas with high sedimentation. Edwards (2010) explained that a range of factors including sedimentation determine the success of newly settled larvae to continue growing.

Although there was no detailed assessment of the fish communities on the nearby reefs, it is obvious that the fish assemblage on the investigated artificial reef was characterized by: first, the dominance of carnivorous fishes in terms of species richness, and second, the dominance of omnivorous fishes in terms of abundance. This pattern might due to two main factors: first, the feeding practices carried out by the submarine divers to attract the fishes to amuse the visitors; second, the site is suffering from illegal regular line-fishing carried out by the local fishermen on-top of the artificial reef area during night.

Several authors concluded that the fish assemblage compositions differ in terms of diversity, abundance, and trophic behavior according to the existing coral coverage and the environmental conditions (Gratwicke and Speight, 2005). Pratchett et al. (2012) discuss fish assemblage changes due to coral cover loss, and conclude that the mean responses vary predictably across key functional fish groups following significant coral loss, with corallivores exhibiting strong and consistent declines in abundance, whereas carnivores, herbivores and planktivores exhibit net increases in abundance. Ferse (2008) investigated the effect of artificial reef structures and coral transplantation on reef fish communities between 2005 and 2007. He concluded that artificial reef structures and coral transplants aided in the establishment of a distinct fish community at all the studied sites in North Sulawesi, Indonesia.

The indicators of artificial reef success differ according to the aim of its establishment (Guidelines of the Atlantic and Gulf States Marine Fisheries Commissions, 2004; Edwards, 2010). Accordingly, the present artificial reef succeeded to fulfill the purpose of its construction because it is succeeded to attract the coral community and fish aggregations necessary for the operation of the submarines asvisitor's attraction. In other words, the continuation of fish and coral inhabitation and growth, either in terms of temporal increase (i.e. 2001-2010) as species diversity and abundance; or in terms of surviving transplanted colonies (i.e. transplanted in 2001 and continue to exist and recorded in 2010); or increase in new grown colonies (i.e. increase in of mature colonies in 2005 and 2010); or increase of fish diversity and abundance, prove the suitability of the artificial reef as a tool for short term coral and fishes colonization. In addition, installing artificial reefs as tourism based facilities could be a successful approach to reduce the potential impact of recreational activities on the natural reefs, especially in areas characterized by reef intensive use by divers and snorkelers such as coral reefs of Hurghada, Red Sea, Egypt. 


\section{ACKNOWLEDGEMENT}

This work was carried out for the Sindbad Submarine Project in Hurghada. The author would like to thank Prof. Mahmoud Hanafy, for his kind assistance during the manuscript writing. Also, many thanks to the divers team of Sindbad Submarine for their valuable assistance during all the stages of the fieldwork.

\section{REFERENCE}

Arthur, R.; Done, T. J.; Marsh, H. andHarriott, V., (2006). Local processes strongly influence post bleaching benthic recovery in the Lakshadweep Islands. Coral Reefs, 25(3): 427440.

Artificial Reef Subcommittees, Atlantic and Gulf States Marine Fisheries Commissions, (2004). Guidelines for marine artificial reef materials, $2^{\text {nd }}$ edition, number $121,198 \mathrm{pp}$.

Babcock, R. C.; Baird, A. H.; Piromvaragorn, S.; Thomson, D. P. and Willis, B. L., (2003). Identification of scleractinian coral recruits from Indo-Pacific reefs. Zoological Studies, 42(1): 211-226.

Clark, S. and Edwards, A. J., (1999). An evaluation of artificial reef structures as tools for marine habitat rehabilitation in the Maldives. Aquat. Conserv. Mar. Freshw. Ecosyst., 9: 5-21.

Coles, S. L., (2003). Coral species diversity and environmental factors in the Arabian Gulf area and the Gulf of Oman: A comparison to the Indo-Pacific Region. Atoll Research Bulletin, the Smithsonian Institution, Washington D. C., 507: 21 pp.

Collins, K. J. and Jensen, A. C. (1996). Artificial reefs. In: C.P. Summerhayes and S. A. Thorpe (eds), Oceanography: an illustrated guide. John Wiley \& Sons, New York, 352pp, ISBN-10: 0470235748.

Edwards, A. J. and Clark, S. (1998). Coral transplantation: a useful management tool or misguided meddling?, Mar. Poll. Bull, 37: 474-87.

Edwards, A. J. and Gomez, E. D. (2007). Reef restoration: Concepts and guidelines: Making sensible management choices in the face of uncertainty. Coral Reef Targeted Research andCapacity Building for Management Programme: St Lucia, Australia.

Edwards, A. J. (2010). Reef Rehabilitation Manual. Coral Reef Targeted Research and Capacity Building for Management Program: St Lucia, Australia.

English, S.; Wilkinson, C. and Baker, V. (1997). Survey manual for tropical marine resources.ASEAN-Australia Marine Science Project: Living Coastal Resources, Australian Institute of Marine Science, PMB No. 3, Townsville Mail Centre, Australia.

Epstein, N.; Bak, R. P. M. and Rinkevich, B. (2003). Applying forest restoration principles to coral reef rehabilitation. Aquat. Conserv., 13: 387-395.

Ferse, S. C. A. (2008). Multivariate responses of the coral reef fish community to artificial structures and coral transplants. Proc. of the $11^{\text {th }}$ Int. Coral Reef Symp, Ft. Lauderdale, Florida.

Ferse, S. C. A.; Nugues, M. M.; Romatzki, S. B. C. and Kunzmann, A., (2013). Examining the Use of Mass Transplantation of Brooding and Spawning Corals to Support Natural Coral Recruitment in Sulawesi/Indonesia. Restoration Ecology. doi: 10.1111/rec.12004.

Gratwicke, B. and Speight, M. R. (2005). The relationship between fishspecies richness, abundance and habitat complexity in a range ofshallow tropical marine habitats. J. Fish Biol., 66:650-667.

Grove, R. S. (1982). Artificial reefs as a resource management option for sitting coastal power stations in southern California. Mar. Fish. Rev., 44: 24-27.

Kotb, M. M. A.; Abou Zeid, M. M. and Hanafy, M. H. (2001). Overall evaluation of the coral reef status along the Egyptian Red Sea coast.Conference of the Italian Society of Marine Biology (31 ${ }^{\circ}$ SIBM), 13-20 May 2000, Sharm El-Sheikh, Egypt. Biol. Mar. Medit., 8(1): 15-32. 
Kotb, M. M. A. (2003). Transplantation of corals as an approach to rehabilitate the degraded reefs in the Egyptian Red Sea. Proc. $1^{\text {st }}$ Egyptian International Conference for Protected Areas \& Sustainable Development, Sharm El-Sheikh, Egypt, 23-26 October 2002. Egyptian Journal of Biology, 5.

Kotb, M. M. A.; Hanafy, M. H.; Rirache, H.; Matsumura, S.; Al-Sofiani, A. A.; Ahmed, A. G.;Bawazir, G. and Al-Horani, F. A. (2008). Status of Coral Reefs in the Red Sea and Gulf of Aden, in: Wilkinson C. (ed.), Status of coral reefs of the world, (2008). Australian Institute of Marine Science, Townsville, Queensland, Australia, pp 67-78.

Pratchett, M.; Hoey, A.; Coker, D. and Gardiner, N. (2012). Interdependence between reef fishes and scleractinian corals.Proc. of the $12^{\text {th }}$ Int. Coral Reef Sym., Cairns, Australia, $13 \mathrm{C}$ Ecological effects of habitat degradation.

Precht, W. F. (2006). Coral reef restoration handbook. CRC Press LLC.

Seaman, W. and Sprague, L. M., 1991.Artificial habitats for marine and freshwater fisheries. Academic Press, Inc.

Seaman, W. (2000). Artificial reef evaluation: with application to natural marine habitats. CRC Press LLC.

vanTreeck, P. and Schuhmacher, H. (1999). Mass Diving Tourism-A New Dimension Calls for New Management Approaches. Mar Pollut Bull, 37:499-504.

Yap, H. T. (2000). The case for restoration of tropical coastal ecosystems.Ocean Coast. Manage, 43: 841-851.

Yap, H. T. (2003). Coral reef "restoration" and coral transplantation. Mar. Poll. Bull., 46529.

Zaidnuddin I., Abdul Razak L., (2000). Fish standing stock observation at the artificial reefs of PulauPayar, Kedah, in: M. Shariff, F. M. Yusoff, N. Gopinath, H. M. Ibrahim, R. A. Nik Mustaphaf (eds.). International Conference on the Straits of Malacca.Malacca Straits Research and Development Center (MASDEC), University Putra Malaysia, Serdang, Malaysia, pp 89-97.

\footnotetext{
ARABIC SUMMARY

استيطان المرجان وتجمعات الأسماك لحيود مرجاتية صناعية أمام ساحل الغردقة، البحر الأحمر، مصر

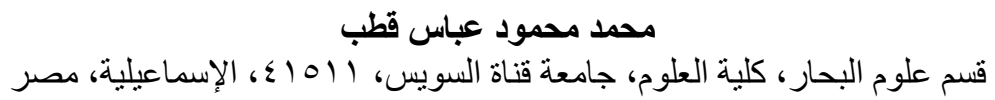

بريد إليكترونى: Kotb13@gmail.com

تم استيطان حيود مرجانية صناعية تحت الماء بغرض إقامة أنشطة سياحية وترفيهية، وتم وضع برنامج

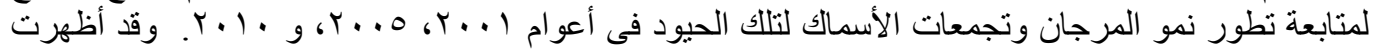

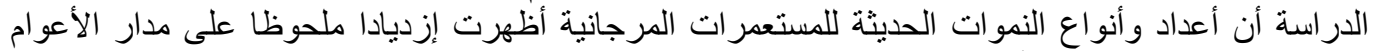

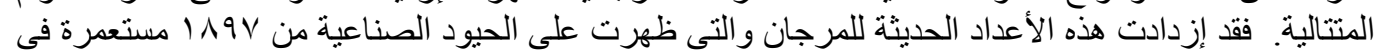

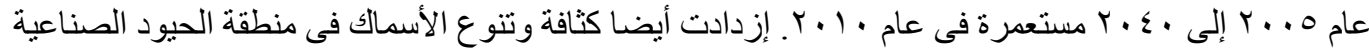

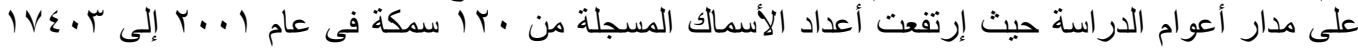

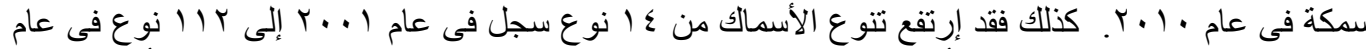

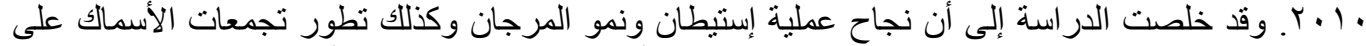
الحيود الصناعية يرجح فكرة إستخدام الحيود الصناعية كأحد التوجهات العملية للتأهيل والحفاظ على على الحيود الطبيعية وكذلك لتقليل الآثار السلبية المتوقعة من الأنشطة الترفيهية والترويحية التية على الثعاب المرجانية الطبيعية للسو احل المصرية على البحر الأحمر.
} 